\title{
ISU PERTEMBUNGAN SOSIAL DALAM NOVEL KE HUJUNG USIA BERDASARKAN TEORI KONFLIK FUNGSIONAL COSER
}

\section{(Issues of Social Conflict in Ke Hujung Usia based on Coser's Functional Conflict Theory)}

\author{
Umairah Shafei \\ umairahshafei@gmail.com
}

Fakulti Penulisan Kreatif dan Filem, Akademi Seni Budaya dan Warisan Kebangsaan (ASWARA)

Published online: 1 December 2020

To Cite: Umairah Shafei. (2020). Isu Pertembungan Sosial dalam Novel Ke Hujung Usia Berdasarkan Teori Konflik Fungsional Coser. Malay Literature, 33(2), 243-264.

\begin{abstract}
Abstrak
Kajian ini bertujuan memahami bentuk-bentuk konflik sosial dalam novel Ke Hujung Usia (2018) karya A. Rahman C.M. berdasarkan Teori Konflik Fungsional Lewis A. Coser yang meletakkan konflik sebagai indikator suatu hubungan yang sihat dalam pembentukan sesebuah struktur masyarakat. Pertembungan berlaku antara watak-watak dalam novel tersebut seperti Tuk Aki, Tuan Guru Haji Munir, pegawai-pegawai Pejabat Daerah, Rasol (Setiausaha Politik Menteri Besar), Umar yang mewakili para pelajar di Pondok Haji Hamid. Konflik antara watakwatak tersebut memberikan implikasi yang positif kepada integrasi, kesepakatan serta kekuatan kelompok dalam kalangan para pelajar dan kedudukan Tuk Aki sendiri sebagai mudir di pusat pendidikan agama tersebut. Berdasarkan pandangan Coser, konflik tidak bersifat negatif kerana pertembungan kelompok luar merupakan peristiwa normal yang sebenarnya dapat memperkuat struktur sosial. Dengan hal yang demikian, Coser menolak pandangan bahawa ketiadaan konflik sebagai indikator kepada kekuatan dan kestabilan sesuatu hubungan. Berdasarkan pemikiran Coser, konflik Tuk Aki dan kelompok luar telah membantu mengukuhkan hubungan struktural, selain meningkatkan integrasi sesama
\end{abstract}




\title{
MALAY LITERATURE VOLUME 33 NUMBER 2 DECEMBER 2020
}

pelajar yang dipimpin oleh Umar. Tahap kesepakatan kelompok sosial tersebut wujud kerana sesebuah konflik memiliki komunikasi dua hala dan peranan injap keselamatan sebagai medium untuk mengawal konflik yang peranannya dimainkan oleh Tuk Aki.

Kata kunci: Konflik fungsional, kelompok dalam, kelompok luar, indikator, injap keselamatan

\begin{abstract}
This research intends to prove social conflict in the novel Ke Hujung Usia (2018) by A. Rahman C.M. based on Lewis A. Coser's Functional Conflict Theory, which places conflict as an indicator of a healthy relationship in the social structure. The conflicts presented between characters in the novel include clashes involving Tuk Aki, Tuan Guru Haji Munir, District Office officials, Rasol (the Political Secretary of the Chief Minister), and Umar, who represents the students at Pondok Haji Hamid, and others. The conflicts between the characters have a positive influence on the integration, consensus and strength of the in-group among the students, and on the position of Tuk Aki himself, as the administrator of the centre of religious education. Based on Coser's theory, conflict is not negative because the clashes of out-group are normal due to the positive impact on the strength of social structure. Thus, Coser rejected the argument that absence of conflict is an indicator of the strength and stability of a relationship. Based on the thought of Coser, the conflict between Tuk Aki and the out-group help to strengthen structural relations, in addition to enhancing the integration of the students who are led by Umar. The social group consensus exists because there is two-way communication in the conflict, and because Tuk Aki plays the role of the safety valve to control the conflict.
\end{abstract}

Keywords: Functional conflict, in-group, out-group, indicator, safety valve

\section{PENDAHULUAN}

Karya sastera dalam semua genre merupakan cerminan daripada realiti sehingga semua persoalan dan permasalahan yang dihadirkan merupakan gambaran kehidupan dan kenyataan sosial dalam pelbagai peristiwa (Abrams, 1997, pp. 113-114). Istilah cermin dalam karya sastera merupakan istilah yang merujuk pelbagai pantulan realiti dalam sesebuah masyarakat yang diketengahkan oleh pengarang. Sebagai cerminan kehidupan masyarakat, novel sebagai salah satu karya sastera juga merupakan gambaran masalah 
yang terjadi dalam masyarakat. Karya sastera juga merupakan gambaran hubungan setiap anggota sosial dengan sistem masyarakat mereka yang tidak dapat dipisahkan daripada wujudnya kepentingan tertentu. Perbezaan kepentingan ini secara tidak langsung mewujudkan konflik fizikal dan konflik internal kerana secara realitinya, manusia dilahirkan seorang diri, namun mereka harus hidup bermasyarakat dan memerlukan hubungan dengan manusia lain dalam sistem yang disepakati secara kolektif. Hubungan tersebut antara lain bersifat saling mempengaruhi dan juga suatu kesedaran untuk saling bekerjasama. Namun begitu, disebabkan oleh kepentingan individu dan kelompok yang saling berbeza, maka wujud pertembungan tertentu yang akan menjerumuskan kepada konflik fizikal dan internal yang berbahaya (Coser, 1970, p. 38, Ritzer \& Goodman, 2014, pp. 285-286).

Sesebuah karya sastera merupakan satu daripada medium dan cara seseorang pengarang membicarakan atau mengupas segenap konflik tersebut. Keadaan ini meletakkan sesebuah karya sastera sebagai wacana kepada pemikiran pengarangnya yang dihubungkan dengan isu-isu masyarakat dan persoalan yang berkaitan dengan hubungan antara kelas sosial dalam masyarakat, sama ada konflik secara negatif mahupun positif. Kedudukan ini juga meletakkan karya sastera sebagai dokumen sosial atau dokumen kemanusiaan tentang keadaan masyarakat serta pemikiran sosial yang menjadi latar penceritaan sesebuah karya, selain berfungsi sebagai sosiobudaya yang mencatatkan perilaku budaya, politik dan ekonomi sesebuah masyarakat tertentu, pada masa tertentu dan dalam situasi tertentu (Umar Junus, 1986, pp. 13-14). Sebagai bidang kreatif, karya sastera bukanlah sebuah gambaran secara lengkap dan realiti kerana sastera dianggap sebuah dunia fiktif dan imaginatif. Karya sastera tetap memberikan tumpuan terhadap konflik, persoalan kehidupan dan interaksi antara manusia dengan sistem atau peraturan hidupan dan sebagainya. Maksudnya, sastera mengangkat manusia sebagai fokus utama yang hidup dalam latar, persoalan, struktur dan dunia kreatif yang dibina oleh seseorang pengarang dengan kepelbagaian persoalan tertentu. Elemen konflik yang diangkat dalam wacana kreatif oleh seseorang pengarang untuk memperlihatkan kehidupan manusia secara realiti tidak terlepas daripada pertembungan kepentingan dan kehendak masing-masing. Oleh itu, karya sastera berfungsi sebagai rakaman dan dokumentasi tentang konflik tertentu yang diangkat secara fiktif sebagai tema karya sastera, sama ada novel, cerpen, drama dan filem. Dalam hal ini, konflik muncul sebagai tema asas kepada sebahagian besar karya sastera, sama ada konflik internal pada watak-watak, watak sesama watak, watak dan persekitaran, serta watak dan sistem sosial mereka. 


\section{MALAY LITERATURE VOLUME 33 NUMBER 2 DECEMBER 2020}

Konflik secara etimologi bermaksud pertengkaran, perkelahian, perselisihan pendapat atau keinginan, pertembungan kepentingan yang berbeza antara kelas sosial atau individu tertentu. Menurut Gidden \& Jonathan, konflik bermakna "... the overt struggle between individuals or groups within a society, or between nation states", iaitu pertentangan atau pertembungan secara terbuka antara individu atau kelompok dalam sesebuah sistem sosial atau bangsa (2004, p. 116). Konflik juga merupakan satu pertembungan yang tidak dapat dielakkan dalam sesebuah sistem sosial kerana setiap kelompok memiliki kepentingan masing-masing yang kadang-kadang akan mengarah kepada gerakan kekerasan atau konflik fizikal.

Conflict is thus designed to resolve dualism: it is a way to achieving some kind of unity, even if it be through the annihilation of one of the conflicting parties. This is roughly parallel to the fact that it is the most violent.

(Turner, 1975, p. 84)

Menurut Turner, konflik berlaku kerana masyarakat merupakan sebuah sistem sosial yang tidak statik dan sentiasa berubah sehingga akan berlaku perubahan tertentu yang memberikan impak positif dan negatif terhadap masyarakat. Ekoran daripada keadaan tersebut, setiap individu atau kelompok sentiasa berusaha untuk memenuhi keperluan dan keinginan masing-masing yang berbeza dengan kelompok lain. Pertembungan kepentingan sosial ini akhirnya akan membawa kepada konflik terutama yang menjurus kepada aspek fizikal, ideologi dan intelektual yang memberikan kesan besar terhadap struktur sosial masyarakat. Dalam perspektif ini, Turner menjelaskan, teori konflik menjadi komponen yang penting sebagai kayu ukur atau acuan untuk memahami pembentukan, peranan dan kesan sesebuah konflik terhadap kelompok dan kelas dalam kehidupan sosial masyarakat:

Any theory or collection of theories that emphasizes the role of conflict, especially between groups and classes, in human societies.

(Turner, 2004, p. 117)

Dalam sesebuah karya sastera, konsep konflik ialah pertembungan dramatik antara dua kelompok watak sehingga menimbulkan persaingan untuk mempertahankan identiti serta hak kelompok. Konsep ini merujuk 
paparan konflik antara watak dengan watak lain (protagonis-antagonis) serta watak dan persekitaran (Puji Santoso, 2000, pp. 251-253). Secara langsung, konflik dalam karya kreatif menjadi sebahagian daripada fenomena sosial yang difiksyenkan untuk memperlihatkan perbezaan kepentingan watak akibat faktor sosioekonomi dan sosiobudaya yang disebabkan oleh kapitalismesibernatik seperti yang dimuatkan dalam novel-novel Melayu mutakhir di negara ini. Konflik dalam sesebuah novel misalnya, merupakan gambaran penulis berdasarkan peristiwa atau fenomena sosial yang dialaminya selama berada dalam masyarakat tertentu. Pengarang turut mengalami fenomena sosial seperti yang dialami oleh khalayak mereka dan karya tersebut merupakan cerminan tentang isu-isu yang berlaku di sekeliling dunia kepengarangannya. Dengan kata lain, novel mengetengahkan kehidupan sebagai sebuah kenyataan sosial, walaupun hanya peniruan terhadap dunia subjektif manusia.

Novel Ke Hujung Usia (2018) oleh A. Rahman C.M. misalnya, merupakan gambaran tentang konflik sosial yang berkaitan antara institusi agama (sekolah pondok tradisional) dengan sistem pentadbiran kerajaan. Secara umumnya, konflik yang diangkat oleh pengarang ini dapat difahami sebagai cerminan realiti yang masih wujud dalam kalangan masyarakat Melayu kontemporari yang memperlihatkan satu demi satu sistem pendidikan sekolah pondok tradisional mulai hilang dan digantikan dengan sistem pendidikan agama yang moden yang ditadbir urus oleh kerajaan. Berdasarkan teori konflik oleh ahli sosiologi Jerman, Lewis A. Coser (1913-2003), konflik sosial dalam novel ini merujuk dua aspek utama, iaitu proses interaksi sosial yang melibatkan hubungan kelompok dalam dan kelompok luar. Kelompok dalam merujuk konflik internal atau konflik psikologi pada individu atau kumpulan ekoran terdapatnya rangsangan daripada peristiwa tertentu seperti kekecewaan, sedih dan marah. Konflik kelompok luar pula merujuk konflik ekoran daripada hubungan dan pertembungan kepentingan dengan kelompok lain. Walau bagaimanapun, berdasarkan pandangan Coser, kerjasama internal dan integrasi kelompok dalam akan bertambah tinggi apabila konflik dengan kelompok luar bertambah besar (Coser, 2001, p. 89, Ritzer \& Goodman, 2004, pp. 231-232). Hal ini menjadi faktor kepada pembentukan hubungan antara kelompok atau hubungan individu dengan sistem sosial mereka yang boleh memperkuat kesedaran internal mereka yang disebut sebagai konflik realistik dan bukan realistik. Hal ini disimbolkan melalui watak seperti Tuk Aki, Nek Leha, Munir, para pelajar di sekolah pondok Tuk Aki, dan pegawaipegawai Pejabat Daerah dan sebagainya. Namun begitu, dalam pemahaman Coser, konflik yang muncul tidak akan memberikan impak terhadap struktur 
sosial, sebaliknya akan membentuk kesatuan atau kehidupan sosial bersama dan secara keseluruhan akan bersifat positif.

Objektif kajian ini adalah untuk memahami elemen konflik dalam novel, dan membuktikan bahawa konflik berjaya meningkatkan solidariti internal dan eksternal pada watak serta kelompok sosial dengan menerapkan prinsip teori konflik fungsional Lewis A. Coser dalam novel Ke Hujung Usia oleh A. Rahman C.M.

\section{Teori Konflik Lewis A. Coser}

Lewis A. Coser dilahirkan di Berlin, Jerman pada 27 November 1913 dalam keluarga berketurunan Yahudi. Beliau merupakan profesor dalam bidang sosiologi yang memberikan tumpuan terhadap pemikiran tentang konflik sosial. Konsep konflik yang dikemukakan oleh Coser secara asasnya merupakan adaptasi daripada pemikiran struktural fungsional oleh Talcott Parsons dan Robert K. Merton serta teori konflik interaksi simbolik yang dikembangkan oleh Georg Simmel (1858-1918). Adaptasi terhadap teori fungsional dan konflik tersebut telah membawa pemikiran Coser kepada kerangka konflik yang meletakkan fungsi positif sesebuah konflik sosial yang merupakan medium untuk mempertahankan, mempersatukan dan mengukuhkan sesebuah sistem sosial yang ada. Pandangan Coser ini telah membawa kepada wacana konflik realistik dan bukan realistik yang merupakan satu pemikiran tentang kekecewaan terhadap keinginan tertentu masyarakat yang mempunyai kecenderungan konflik tetapi akan mempunyai nilai positif melalui konsep injap keselamatan, iaitu moderator yang menjadi penghubung antara kelompok yang berkonflik. Sesebuah konflik dapat berfungsi positif atau negatif bergantung pada jenis isu yang merupakan subjek konflik yang berkembang dalam sesebuah masyarakat (Coser, 2001, pp. 4-6). Beliau berpendapat, konflik fungsional positif terbentuk apabila tidak ada konflik yang berhubung dengan nilai asas sesebuah kelompok seperti agama, kebudayaan dan unsur struktural asas yang lain. Sebaliknya, sesuatu konflik akan menjadi negatif apabila nilai-nilai tersebut menjadi fokus oleh masyarakat yang bertujuan untuk memperlihatkan keunggulan masing-masing dalam aspek tersebut.

Coser, yang melakukan penyelidikan selama lebih 20 tahun untuk memahami struktur sosial terutama masyarakat Eropah serta Jerman, mendapati konflik yang merupakan elemen penting dalam pembentukan sesebuah struktur sosial sebenarnya berkonotasi positif berbanding dengan pandangan 
negatif seperti yang dikemukakan oleh pemikir lain seperti Dukeheim, Weber, Marx dan Ralf Dahrendorf. Coser turut menilai dua perspektif yang berbeza, iaitu teori strukturalisme fungsional pada abad ke-20 oleh Parsons dan teori konflik yang dikemukakan oleh Marx. Beliau telah mengambil jalan tengah dengan menggabungkan dan mengadaptasi kedua-dua pendekatan ini untuk memahami konflik yang berkembang dalam sesebuah masyarakat (I.B Wirawan, 2014, pp. 82-83). Coser mengakui bahawa beberapa susunan struktural merupakan impak daripada persetujuan dan kesepakatan, suatu proses yang ditonjolkan oleh aliran strukturalisme fungsional, dan pada masa yang sama turut dipengaruhi oleh pemikiran konflik Marx.

Hasil daripada gabungan dan adaptasi pemikiran struktural fungsional dan konflik tersebut, Coser mendapati pelbagai sumbangan konflik yang berfungsi positif, iaitu membentuk serta mempertahankan struktur suatu kelompok tertentu. Sama seperti pemikir teori konflik yang lain, Coser juga berpendapat konflik merupakan satu bentuk interaksi sosial yang asas dan proses konflik tersebut berkait rapat dengan bentuk alternatif seperti kerjasama dalam pelbagai cara. Hal ini sangat berbeza dengan pemikir konflik klasik seperti Weber, Dukheim dan Marx, serta beberapa pemikir konflik kontemporari seperti Rendall Collins dan Dahrendorf yang berpendapat bahawa konflik sosial sinonim dengan impak negatif terhadap struktur sosial, atau memiliki kesan positif dan negatif. Sebaliknya, Coser menekankan bahawa konflik sosial cenderung memiliki kesan positif terhadap masyarakat. Beliau mengemukakan teori konflik dengan membahaskan tentang permusuhan dalam hubungan sosial yang akrab yang memiliki makna berdasarkan keperluan dan kehendak sesuatu sistem sosial (Poloma, 1992, pp. 113-117; Coser, 2001, pp. 77-79). Dengan kata lain, dalam sistem sosial, konflik merupakan satu pendekatan antara individu atau kelompok untuk memahami antara satu sama lain yang disebut oleh Coser sebagai satu kaedah komunikasi internal dan eksternal.

Apabila konflik berkembang dalam hubungan sosial yang intim, maka pemisahan antara konflik realiti dan bukan realiti sangat sukar untuk dielakkan kerana semakin rapat sesebuah hubungan sosial, semakin besar rasa kasih sayang yang sudah tertanam dan semakin besar juga kecenderungan untuk menguasai berbanding dengan rasa permusuhan. Berdasarkan adaptasi daripada teori konflik Simmel, Coser mentakrifkan kedudukan konflik fungsional ini sebagai suatu bentuk kerjasama positif kerana mampu meredakan ketegangan yang terjadi dalam suatu kelompok masyarakat dengan menguatkan keseimbangan struktural mereka seperti yang dijelaskan: 
MALAY LITERATURE VOLUME 33 NUMBER 2 DECEMBER 2020

Conflict is not always dysfunctional for the relationship within which is occurs; often conflict is necessary to maintain such a relationship.

(Coser, 1968, p. 70)

Berdasarkan pemahaman ini, Coser mengemukakan pandangan bahawa tahap persetujuan kelompok merupakan hubungan dua hala paling penting dalam konteks konflik sebagai medium mengukuhkan struktur sosial kelompok. Oleh itu, konflik merupakan proses sosial yang merupakan mekanisme untuk mengukuhkan kembali identiti individu atau kelompok berkenaan. Dengan kata lain, konflik tidak merosak atau bersifat disfungsional kepada sesebuah sistem sosial kerana konflik sering berkonotasi positif (Coser, 1970, pp. 72-73). Konflik dapat berlaku antara individu, kelompok atau antara individu dengan kelompok, selain konflik antara kelompok dengan kelompok. Perkembangan ini meletakkan konflik menjadi unsur interaksi yang sangat penting dan sama sekali tidak boleh dianggap sebagai sesuatu yang negatif kepada individu atau sesebuah masyarakat. Dalam konteks ini, pemikiran Coser berbeza dengan wacana konflik yang dikemukakan oleh Marx atau Dahrendorf yang meletakkan setiap kelompok sosial memiliki konflik yang cenderung bersifat negatif, ekoran kepentingan tertentu setiap kelompok. Pemikiran konflik fungsional Coser menekankan makna positif di sebalik sesebuah konflik yang ditakrifkan sebagai bentuk alternatif kepada kerjasama antara individu atau kelompok dan tidak bersifat disfungsional. Secara keseluruhan, wacana konflik Coser menjurus kepada fungsi positif dalam masyarakat untuk menyatukan kembali kelompok yang sedang mengalami konflik sosial.

Menurut Coser, konflik merupakan kualiti produktif daya hidup masyarakat yang akan menghasilkan perubahan atau peningkatan dalam integrasi dan kesepakatan sosial (2001, pp. 81-83). Dalam aspek lain, Coser berpendapat bahawa konflik merupakan mekanisme perubahan sosial dan penyesuaian yang dapat memberikan peranan positif dalam masyarakat. Beliau menghubungkan teori struktural fungsional seperti yang dikemukakan oleh Parsons dan Merton dengan teori konflik seperti yang dikemukakan oleh Waber, Dukheim dan Marx. Persoalan ini dapat dilihat melalui kecenderungan beliau terhadap fungsi integratif konflik dalam sistem sosial dan keberadaan konflik terhadap perubahan positif sesebuah sistem sosial. Sama seperti konsep konflik yang dikemukakan oleh Simmel, Coser berpendapat bahawa ada sifat agresif dan permusuhan dalam diri setiap orang atau kelompok sosial, namun sifat tersebut sering muncul dengan dua sisi yang berbeza, 
sama seperti sekeping wang syiling, iaitu agresif dan kemaafan, benci dan sayang, dan lain-lain.

\section{Pembahagian Konflik}

Secara umumnya, Coser membahagikan konflik kepada dua, iaitu konflik realistik dan konflik bukan realistik. Kategori pertama merujuk konflik yang berasal daripada kekecewaan terhadap tuntutan atau permintaan khusus oleh individu atau kelompok terhadap kelompok lain yang mempunyai kedudukan yang lebih tinggi dalam status sosial. Konflik bukan realistik pula merujuk permusuhan yang bersifat ideologi, agama, etnik dan geopolitik. Konflik bukan realistik juga dapat ditakrifkan sebagai konflik yang bukan bertujuan persaingan, sebaliknya keperluan pihak tertentu untuk meredakan atau mengelakkan ketegangan dan perselisihan antara individu atau kelompok (Wallace \& Wolf, 2006, p. 124, Coser, 2001, p. 17). Konflik realistik dan bukan realistik dalam wacana Coser merupakan medium untuk mempertahankan, mempersatukan dan mengukuhkan struktur sosial. Coser mengakui bahawa konflik itu dapat membahayakan keharmonian dan integrasi antara kelompok. Oleh itu, perlu diwujudkan satu pendekatan untuk mengurangkan bahaya tersebut melalui pembinaan konsep injap keselamatan (safety valve), iaitu satu konsep atau mediator untuk meredakan ketegangan. Konsep ini merujuk persetujuan dan kesefahaman antara kelompok sosial untuk meredakan ketegangan. Dengan adanya mediator tersebut, kelompok yang bertikai dapat menyelesaikan konflik tersebut melalui pendekatan fungsional, iaitu berdasarkan fungsi kelompok masing-masing dalam sesebuah sistem sosial.

Selain berbentuk institusi sosial, injap keselamatan tersebut juga berbentuk tindakan atau kebiasaan yang dapat digunakan untuk meredakan ketegangan yang dilaksanakan dengan kesepakatan dan persefahaman seperti agensi kerajaan, tokoh yang dihormati serta kesepakatan yang dicapai melalui rundingan. Dalam hal ini, Coser berpendapat, sesuatu konflik bersifat fungsional (baik) dan bersifat disfungsional (buruk), namun akan berakhir dengan kesepakatan. Namun begitu, sebagai pemikir yang terpengaruh dengan aliran struktural fungsional Parsons dan Merton, Coser cenderung melihat konflik dalam aspek fungsional, bukannya disfungsional. Beliau mendefinisikan konflik sosial sebagai suatu perjuangan terhadap nilai dan pengakuan terhadap status yang dimiliki oleh setiap individu atau kelompok oleh individu atau kumpulan sosial yang lain (1970, p. 107). Dengan adanya konflik, bentuk-bentuk interaksi akan dan mampu mengungkapkan perasaan 
MALAY LITERATURE VOLUME 33 NUMBER 2 DECEMBER 2020

setiap kelompok atau individu yang akhirnya akan mengarah kepada toleransi dan kesepakatan. Oleh itu, konflik dalam wacana Coser cenderung kepada pengukuhan integrasi dan persefahaman yang akan membawa kepada pengukuhan sesebuah struktur sosial.

Sebelum konflik, kelompok tertentu mungkin tidak yakin terhadap kumpulan lain, namun keadaan tersebut akan berubah kerana individu mampu memutuskan untuk mengambil tindakan yang tepat dalam hubungannya dengan musuh. Konflik juga membolehkan kumpulan yang berkonflik saling mendekati atau saling berdamai. Sebaliknya, kelompok yang tidak mempunyai sebarang konflik menunjukkan lemahnya integrasi kelompok tersebut dengan masyarakat. Perbezaan pendapat merupakan sesuatu kebiasaan yang sebenarnya dapat memperkuat struktur sosial. Dengan hal demikian, Coser menolak pandangan bahawa ketiadaan konflik sebagai indikator kekuatan dan kestabilan suatu hubungan. Hal ini disebut oleh Coser sebagai:

Conflict with other group contributes to establishment and reaffirmation of the identity of the group and maintains its boundaries against the surrounding social world.

(Coser, 2012, p. 38)

Kenyataan Coser ini membawa maksud konflik dapat memperkuat kelompoknya masing-masing dan secara tidak langsung, struktur ini tanpa disedari memberikan nilai tersendiri terhadap situasi konflik internal yang mungkin dialami sebelumnya oleh kelompok tertentu yang akan mengarah kepada pengukuhan struktur sesebuah masyarakat. Beliau menjelaskan bahawa konflik dengan kelompok luar akan membantu pengukuhan aspek struktural kedua-dua kelompok atau individu sebagai anggota sosial, selain konflik dengan kelompok luar juga dapat mengukuhkan integrasi kelompok dalam (Coser, 2001, pp. 92-93). Secara keseluruhan, prinsip konflik fungsional Coser menekankan empat prinsip asas tentang kepentingan dan aspek positif sesebuah konflik, iaitu memperkuat solidariti dan saling percaya sesebuah kelompok yang agak longgar. Selain itu, konflik dengan kelompok lain juga dapat mengukuhkan kerjasama anggota dalam masing-masing kelompok, mengaktifkan kelompok yang terpinggir. Konflik juga mampu berfungsi sebagai sebuah komunikasi sosial. 


\section{Sinopsis Ke Hujung Usia}

Novel ini menyorot atau mengangkat kisah kehidupan Tuk Aki sebagai guru dan pemilik pusat pengajian agama, Pondok Haji Hamid yang diwarisi daripada keluarganya. Pelbagai konflik timbul ketika beliau mengurus pondok tersebut yang begitu mencabar keperibadian, kewibawaan dan ketokohannya. Pada masa yang sama, beliau berada dalam dilema dengan pelawaan daripada Tuk Ayah, bekas gurunya yang mahukan Tuk Aki menggantikannya sebagai pimpinan di pusat pengajian serupa di Bermin, Pattani, Thailand. Pada masa yang sama, ada cadangan pihak kerajaan hendak mengambil tanah tapak pondok tersebut untuk dimajukan. Tindakan anak muridnya mengadakan tunjuk perasaan membantah keputusan kerajaan tersebut seterusnya menimbulkan konflik pada watak Tuk Aki. Tambah merumitkan keadaan apabila muncul Haji Munir yang cuba menangguk di air keruh demi kepentingan politik dan kedudukannya, selain terdapat segelintir penduduk kampung yang curiga dan iri hati dengan semua yang dimiliki oleh Tuk Aki. Keadaan tersebut benar-benar meletakkan beliau dan isterinya, Nek Leha dalam konflik dengan sistem sosial dan persekitarannya, konflik dengan individu tertentu (Munir) dan konflik dengan sistem pentadbiran (pihak Pejabat Tanah) selain konflik sosial yang dihadapi oleh Tuk Aki. Walau bagaimanapun, konflik tersebut telah memberikan impak yang positif terutamanya dalam usaha mengukuhkan serta mengeratkan hubungan 37 orang pelajar di Pondok Tuk Aki. Penolakan mereka terhadap usaha kerajaan untuk mengambil tapak sekolah mereka telah mewujudkan satu solidariti kelompok berstruktur yang sebelum ini longgar kerana pelbagai polemik yang muncul. Antaranya, mereka mengalami disintegrasi, atau berkonflik dengan masyarakat lain (kelompok Tuan Guru Haji Munir) dan masyarakat setempat yang berpandangan serong terhadap keberadaan sekolah tersebut, selain ada sikap dengki masyarakat terhadap Tuk Aki. Akhirnya konflik tersebut telah mengikat dan menguatkan kembali hubungan kelompok dalam dan kelompok luar serta watak-watak dalam novel tersebut.

\section{Wacana Konflik Coser dalam Ke Hujung Usia}

Secara keseluruhan, konflik sosial dalam Ke Hujung Usia berdasarkan teori konflik fungsional Coser dapat dibahagikan kepada konflik realistik dan konflik bukan realistik yang dikaitkan dengan watak protagonis dan antagonis. Watak utama dalam novel ini digambarkan oleh pengarang mengalami beberapa konflik yang disebabkan oleh adanya unsur luar yang 
cuba mempengaruhi pimpinan dan pelajar Pondok Haji Hamid yang dipimpin oleh Tuk Aki. Watak Tuk Aki misalnya, mengalami konflik realistik kerana terdapat beberapa rangsangan, seperti jumlah pelajar Pondok Haji Hamid yang semakin berkurangan dan ajakan dan permintaan bekas gurunya, Tuk Ayah supaya Tuk Aki menggantikannya sebagai pimpinan baharu di sekolah pondok di Bermin, Pattani, Thailand. Konflik realistik dalam konteks ini dapat ditakrifkan sebagai konflik yang muncul dalam diri sendiri seseorang ekoran perasaan resah, takut, kecewa, marah atau dilema disebabkan oleh rangsangan tertentu. Dalam novel tersebut, konflik ini berhubungan dengan perasaan individu sendiri, tanpa melibatkan orang lain seperti yang dialami oleh Tuk Aki:

Tuk Aki terbayang wajah Haji Jamal. Wajah lembut itu penuh mengharap padanya. Lama wajah itu singgah dalam mata batinnya. Dari wajah Haji Jamal, muncul wajah Tuk Ayah. Lelaki berusia 90-an itu sudah kelihatan bongkok. Mulut Tuk Ayah dengan bibirnya yang terjuih ke bawah itu seperti merenungnya dengan mata yang tajam. Memang ajal di tangan Tuhan. Itu pegangan kepada mereka yang bertakwa kepada Allah SWT.

(A. Rahman C.M., 2018, pp. 2-3).

Berdasarkan pemikiran konflik Coser, konflik realistik muncul berpunca daripada konflik luaran (hostile behaviour) yang merujuk hubungan dengan individu lain dalam kelompok yang sama atau juga disebut sebagai konflik kumpulan dalam (Coser, 1991, pp. 96-97). Konflik dalaman pada watak Tuk Aki juga muncul apabila wujud kebimbangan tentang masa depan Sekolah Haji Hamid yang mungkin berhadapan dengan penutupan oleh kerajaan untuk dijadikan sekolah menengah agama kerajaan yang berasrama:

Tuk Aki teringat bahawa ayahnya pernah memberitahu sebab-sebab yang tertutup pondok-pondok itu. Ada yang diambil alih oleh kerajaan untuk dijadikan sekolah menengah agama kerajaan yang berasrama. Umpamanya, Pondok Haji Abbas menjadi sekolah menengah agama kerajaan berasrama penuh. Pondok Haji Syafie menjadi sekolah menengah agama harian yang mendapat bantuan penuh daripada kerajaan. Dan ada pula yang terlibat dengan perbalahan keluarga. Pondok Haji Buyung. Tetapi apabila dia meninggal dunia, anak-anaknya ingin membahagikan tanah itu kepada waris.

(A. Rahman C.M., 2018, pp. 9-10) 
Berdasarkan petikan ini, Tuk Aki juga mengalami konflik realistik apabila memikirkan masa depan Sekolah Pondok Haji Hamid yang mungkin mengalami nasib yang sama dengan sekolah-sekolah pondok tradisional lain yang telah diambil alih oleh pihak berkuasa, sama ada untuk dinaik taraf atau untuk tujuan lain. Sebagai pemimpin sekolah pondok tersebut, secara peribadi dia akur dengan semua keputusan kerajaan dan pihak berwajib sekiranya mereka akan mengambil alih tapak Sekolah Pondok Haji Hamid yang diterajuinya, demi kepentingan semua pihak. Kedudukan ini dapat difahami dalam wacana Coser sebagai injap keselamatan yang merujuk persetujuan dan kesefahaman antara kelompok sosial untuk meredakan ketegangan. Hal ini bermakna, dengan adanya mediator tersebut, Tuk Aki yang mewakili sekolah pondoknya, yakin akan dapat menyelesaikan konflik melalui pendekatan fungsional, iaitu berdasarkan fungsi kelompok masingmasing dalam sesebuah sistem sosial. Dia yakin bahawa nasib yang menimpa beberapa sekolah pondok lain tidak akan menimpa Sekolah Pondok Haji Hamid jika wujud kesepakatan dan persefahaman melalui rundingan dengan pihak berwajib dan elit politik tokoh-tokoh yang dihormati.

Konflik realistik juga turut berlaku pada watak Nek Leha berkenaan kesihatan dan keadaan Tuk Aki yang seolah-olah memberikan gambaran tertentu (tidak baik) yang akan berlaku sehingga menimbulkan kebimbangan:

Sebelum terlena, kalbu Nek Leha bertanya, apakah alamat malam itu yang akan diterimanya. Tidak pernah Tuk Aki tidur awal begini. Paling awal Tuk Aki masuk tidur ketika Nek Leha sudah diulit mimpi. Dia tidak tahu pukul berapa. Tetapi malam itu terbalik. Tuk Aki dulu yang dibuai mimpi, sedangkan dirinya masih belum mengantuk.

(A. Rahman C.M., 2018, p. 205).

Perasaan dan konflik internal yang dihadapi oleh Nek Leha tersebut, menurut Coser, semakin dekat suatu hubungan semakin besar rasa kasih sayang yang sudah tertanam, sehingga semakin besar kecenderungan untuk terus memahami kelompok atau individu lain (Coser, 1956, pp. 77-78). Dalam wacana Coser, hal ini bermaksud, hubungan antara kelompok atau individu dalam tempoh yang lama, tidak hanya bersifat hubungan secara fizikal, tetapi juga hubungan mental (psikologi) yang menghapuskan seluruh rasa permusuhan atau syak wasangka. Hubungan ini dikenali sebagai hubungan primer yang membolehkan konflik diselesaikan berdasarkan pengertian, persefahaman dan kesepakatan kerana antara individu atau kelompok 
tersebut memiliki sejarah hubungan yang panjang. Keadaan ini dalam wacana konflik Coser, difahami sebagai konflik realistik, iaitu konflik yang diatur (setting) kerana setiap individu atau kelompok memiliki kepentingan antara satu sama lain. Dalam konteks ini, muncul konflik realistik pada watak Tuk Aki dan Nek Leha kerana kedua-duanya mempunyai hubungan internal dan eksternal yang panjang sebagai suami isteri. Begitu juga keterikatan antara Tuk Aki dengan Pondok Haji Hamid yang begitu lama sehingga tindakan serta beberapa keputusan Pejabat Daerah untuk mengambil tapak pondok tersebut untuk tujuan pembangunan telah menimbulkan konflik realistik. Beliau khuatir tentang masa depan pusat pengajian tersebut, selain ingin memastikan legasi arwah datuknya (Haji Hamid) dalam bidang pendidikan agama dan al-Quran dapat terus bertahan.

Konflik bukan realistik merujuk konflik yang bukan bertujuan persaingan berbentuk antagonis, tetapi merupakan sebahagian daripada keperluan individu atau kelompok untuk meredakan ketegangan (Coser, 1956, p. 49). Konflik ini muncul apabila terdapat individu atau kelompok yang berkepentingan menggunakan subjek atau isu tertentu untuk kepentingan yang berbeza. Dalam konteks novel ini, watak Riduan, Zaiton, Ramli dan Ruzaimi yang merupakan pegawai daripada Pejabat Daerah telah menggunakan perdebatan dan isu sejarah sebagai medium untuk mencari kelemahan Tuk Aki dengan harapan beliau akur dengan keputusan kerajaan mengambil tanah tapak Pondok Haji Hamid untuk pembangunan:

\footnotetext{
"Tapi Tuk Aki tetap yakin Terengganu lebih dulu menerima kedatangan Islam? Bukan Melaka? Begitu?”

"Ya saya yakin. Buktinya batu bersurat. Kalau tak, dari mana batu bersurat itu? Takkan turun dari langit," kata Tuk Aki dengan suara yang kejap dan penuh yakin.
}

\section{(A. Rahman C.M., 2018, p. 22)}

Merujuk petikan tersebut, Tuk Aki sedar bentuk "perangkap yang dipasang" oleh pegawai dan kakitangan Pejabat Daerah tersebut, namun dia tidak memperlihatkan konflik realistik pada dirinya bagi menghormati para tetamunya tersebut. Berdasarkan wacana Coser, konflik bukan realistik ini bukanlah suatu bentuk permusuhan kerana setiap pihak yang mempunyai kepentingan tetap mempertahankan keberadaan kelompok lain. Pegawai Pejabat Daerah misalnya, tidak bertujuan mewujudkan permusuhan dengan Tuk Aki dan para pelajar di Pondok Haji Hamid sebaliknya mewujudkan 
hubungan sekunder yang dapat difahami dengan ganjaran lain seperti ganti rugi atau penyediaan tempat baharu untuk meneruskan legasi pendidikan pusat pendidikan agama tersebut. Oleh itu, dalam perspektif konflik Coser, semakin dekat suatu hubungan semakin besar rasa kasih sayang yang sudah wujud, sehingga kecenderungan untuk mengelakkan rasa permusuhan semakin besar (Coser, 2001, p. 49). Dalam pengertian ini, Coser menolak pandangan Marx bahawa konflik merupakan salah satu bentuk eksploitasi besar-besaran yang dilakukan oleh kelas kapitalis dan elit politik terhadap kelas proletarian (buruh, pekerja dan petani).

Menurut Marx, sejarah masyarakat manusia ialah sejarah perjuangan kelas, yang akan memunculkan konflik antara kelompok borjuis dengan kelompok proletarian (kelas bawah). Kelompok yang menyedari bahawa kedudukannya sebagai kelas bawah secara kolektif berpotensi melakukan gerakan revolusi terhadap kelas borjuis (Parekh, 2015, p. 203). Konflik antara kelas inilah yang kemudian melahirkan perubahan dalam masyarakat yang disebut sebagai masyarakat sosialis. Keadaan ini muncul kerana dalam pemahaman Marx, konflik sangat berhubungan dengan beberapa konsep tentang kelas sosial, perubahan sosial, serta kekuasaan dan negara. Sebaliknya, Coser menekankan konflik merupakan satu kaedah untuk mewujudkan kerukunan dan kedamaian antara individu atau kelompok yang merupakan proses yang membentuk, menyatukan dan memelihara struktur sosial. Selain itu, konflik dalam perspektif Coser dapat menjaga had dan sempadan kepentingan setiap individu atau kelompok sehingga mampu membendung sebarang konflik yang negatif, bahkan turut menguatkan identiti kelompok masing-masing. Oleh itu, secara langsung, konflik dapat memperkuat solidariti dan persefahaman kelompok sosial yang longgar akibat perbezaan kepentingan. Dalam konteks novel Ke Hujung Usia, konflik antara Tuk Aki dengan pegawai Pejabat Daerah misalnya, telah menguatkan solidariti para pelajar di Pondok Haji Hamid untuk mempertahankan kemandirian pusat pengajian mereka:

Ketika Tuk Aki berteka-teki terhadap kehilangan semua anak muridnya di pondok pagi itu, Umar dengan rakan-rakannya berdiri secara aman di muka pintu masuk ke pejabat Menteri Besar. Di tangan mereka ada sepanduk. Di tangan mereka ada kain rentang. Di tangan mereka ada poster. "Pondok Haji Hamid juga untuk faedah orang ramai. Ia tidak boleh ditutup". "Pondok Haji Hamid juga untuk faedah awam. Ia tidak boleh ditutup". "Pondok Haji Hamid tidak boleh ditutup". "Kami mahu Pondok Haji Hamid dikekalkan". "Selamatkan Pondok Haji Hamid".

(A. Rahman C.M., 2018, pp. 102-103) 
Berdasarkan perspektif konflik fungsional Coser, tindakan berdasarkan solidariti yang dipimpin oleh Umar dan pelajar daripada Pondok Haji Hamid yang lain untuk mempertahankan pondok terbentuk kerana adanya konflik dengan Pejabat Daerah yang ingin mengambil pusat pengajian tersebut untuk dibangunkan sebagai kawasan komersial. Dalam pemahaman Coser, konflik merupakan medium atau alat untuk mempertahankan, mempersatukan dan mengukuhkan sistem sosial yang ada. Unsur positif konflik tersebut ialah semua aspek yang berkaitan rapat dengan hubungan dinamik antara kelompok dalam dengan kelompok luar (Coser, 1956, pp. 83-84). Dengan kata lain, kekuatan solidariti dan kerjasama kelompok (para pelajar yang dipimpin oleh Umar) menjadi kekuatan internal meskipun mewujudkan konflik dengan Tuk Aki yang tidak bersetuju dengan tindakan tersebut kerana menentang pemerintah itu sebahagian daripada dosa dan mencemarkan maruah Pondok Haji Hamid. Ketidaksetujuan tersebut kerana Tuk Aki sedar adanya kepentingan daripada kelompok luar yang dipimpin oleh Tuan Guru Haji Munir yang cuba mengambil kesempatan daripada konflik tersebut untuk kepentingan politiknya.

Tuan Guru Haji Munir semakin galak. Dia makin lantang bersuara membakar semangat Umar dan rakan-rakannya. Sorakan dan laungan "Macam Firaun" bertalu-talu. Sorakan dan laungan "Macam taghut" bertali-tali. Umar dan rakan-rakan ada yang sudah kehilangan punca. Mereka berlompat-lompatan. Mereka berteriak-teriakan. Tuan Guru Haji Munir dan Ismail makin galak membakar semangat mereka.

\section{(A. Rahman C.M., 2018, p. 104).}

Berdasarkan pemikiran konflik Coser, tindakan Tuan Guru Haji Munir dan pembantunya, Ismail, menguatkan solidariti dan integrasi kelompok dalam kerana konflik dengan kelompok luar (Kerajaan Negeri dan Pejabat Daerah) bertambah besar. Secara langsung, integriti yang semakin tinggi dalam kelompok yang terlibat dengan konflik dapat membantu memperkuat hubungan antara kelompok itu (pelajar Pondok Haji Hamid) dengan kelompok lain (kelompok Tuan Guru Haji Munir) meskipun tuan guru itu mempunyai misi serta kepentingan politik tertentu. Namun begitu, dalam perspektif Coser, konflik yang berlaku antara individu dan kelompok tidak semestinya membawa perubahan kepada struktur sosial yang menjurus kepada permusuhan. Hal ini berbeza dengan pemikiran konflik sebelumnya seperti Dahrendorf yang mengemukakan andaian bahawa sesebuah masyarakat akan sentiasa tunduk 
kepada proses perubahan, pertikaian serta konflik yang ada dalam sistem sosial dan juga pelbagai elemen kemasyarakatan yang seterusnya menyumbang kepada disintegrasi dan perubahan. Beliau berpendapat, setiap masyarakat sentiasa berhadapan dengan pemaksaan terhadap anggotanya oleh kelompok atau elit birokrasi yang memiliki kekuasaan, sehingga menjurus kepada konflik antara sub-sub kelompok. Namun begitu, pada masa yang sama, ada potensi tertentu yang boleh membawa masyarakat kepada kesepakatan dan kerjasama (Dahrendorf, 2018, pp. 13-14). Oleh itu, bagi Dahrendorf, masyarakat memiliki dua wajah, iaitu konflik dan kesepakatan (consensus) yang dikenali sebagai konflik dialektik. Berdasarkan perspektif ini, beliau menekankan bahawa masyarakat tidak akan ada tanpa persetujuan dan konflik. Masyarakat bersatu berdasarkan persetujuan kolektif, namun pada masa yang sama mereka juga berhadapan dengan konflik tertentu yang membawa kepada pemaksaan dan penguasaan oleh elit birokrasi dan kelas kapitalisme. Hal sedemikian berlaku kerana asas kepada pemikiran konflik Dahrendorf ialah kritikan dan penilaian terhadap pemikiran Marx, yang mengemukakan tesis bahawa dalam sesebuah sistem sosial terdapat kapitalisme (borjuis), pemilikan modal dan kawalan serta penguasaan terhadap para buruh, petani dan kelompok pekerja (kelas proletarian).

Keadaan ini meletakkan masyarakat dalam dua wajah yang berbeza kerana setiap masyarakat terpaksa akur kepada perubahan yang merangkumi semua aspek termasuk isu pertembungan gender (Anderson \& Collins, 1992, pp. 33-35). Konflik secara penguasaan dan kesepakatan ini disebut oleh Dahrendorf sebagai konflik dilektika kerana adanya potensi masyarakat yang akan tunduk pada bila-bila masa sahaja terhadap kehendak kelas yang berkuasa, dan pada masa yang sama akan tercetus konflik yang akan membawa kepada perubahan masyarakat secara radikal. Pandangan ini telah ditolak oleh Coser kerana melihat pemikiran Dahrendorf tersebut terlalu berhubung rapat dengan pandangan konflik kelas yang berasaskan hubungan proletarian-borjuis yang dikemukakan oleh Marx.

\section{Fungsi Injap Keselamatan dalam Ke Hujung Usia}

Coser berpendapat injap keselamatan dalam konflik sesebuah sistem sosial berfungsi sebagai jalan keluar yang meredakan permusuhan. Tanpanya, hubungan antara pihak yang bertentangan akan semakin menajam. Injap keselamatan juga berfungsi sebagai satu daripada mekanisme khusus yang digunakan untuk mempertahankan kelompok daripada kemungkinan konflik 
MALAY LITERATURE VOLUME 33 NUMBER 2 DECEMBER 2020

sosial sama ada kelompok dalam mahupun kelompok luar (Coser, 2001, p. 36). Maknanya, injap keselamatan ini akan meredakan konflik tanpa menghancurkan seluruh struktur sosial sekali gus menamatkan pertembungan sosial yang sedang berlaku dengan menyediakan medium kepada kelompok atau individu yang berkonflik ini untuk mengungkapkan keluhan masing-masing. Dengan kata lain, Coser meletakkan injap keselamatan sebagai medium untuk mendamaikan kelompok yang berkonflik demi mempertahankan sistem sosial yang sedia ada. Dalam Ke Hujung Usia, watak injap keselamatan dimainkan oleh Tuk Aki, yang antaranya telah mendamaikan konflik antara Umar dengan para pelajar lain yang ingin mempertahankan pusat pengajian tersebut:

"Tuk Aki, saya Setiausaha Politik Menteri Besar, Tuk Aki tahu apa yang berlaku di pintu pagar masuk pejabat Menteri Besar sekarang?" "Berlaku apa?"

"Anak murid Tuk Aki berkumpul. Mereka adakan tunjuk perasaan." "Tunjuk perasaan apa?" "Mereka membantah niat kerajaan nak ambil tanah tapak pondok Tuk Aki."

(A. Rahman C.M., 2018, p. 105)

Berdasarkan petikan tersebut, Tuk Aki tidak pernah merestui tunjuk perasaan oleh para pelajarnya bagi membantah keputusan kerajaan untuk mengambil tapak sekolah pondok tersebut. Malah, beliau telah menasihatkan Umar dan rakan-rakannya supaya akur dengan semua keputusan oleh pihak berwajib tersebut. Dalam aspek ini, Tuk Aki berfungsi sebagai injap keselamatan seperti yang dikemukakan oleh Coser untuk meredakan konflik tersebut.

Peranan injap keselamatan juga turut dimainkan oleh Menteri Besar yang memberikan jaminan akan memberikan pampasan yang sewajarnya berdasarkan harga semasa tanah milik sekolah pondok tersebut, selain akan menyediakan tapak baharu untuk sekolah tersebut. Hal ini bertujuan untuk meredakan kemarahan dan rasa tidak puas hati para pelajar Tuk Aki:

\footnotetext{
"Beginilah, Tuk Aki. Saya bawa balik kertas projek Tuk Aki. Saya akan baca, SUK akan baca."

"Kami akan timbangkan mana yang patut. Nanti pegawai daerah akan hubungi Tuk Aki."

Mungkin dia akan bawa Tuk Aki lihat tanah yang dicadangkan untuk
} 
ganti tanah ini."

"Bagaimana?"

Berdasarkan wacana konflik fungsional Coser, peranan pihak polis dan Pejabat Menteri Besar, serta kewibawaan Tuk Aki sebagai tokoh agama yang disegani oleh pelbagai pihak terutama para pelajarnya berfungsi sebagai injap keselamatan untuk meredakan konflik ekoran perebutan tapak Pondok Haji Hamid. Kedudukan pihak ini sejajar dengan pemikiran Coser bahawa injap keselamatan bertujuan mempertahankan kelompok-kelompok daripada kemungkinan konflik sosial dan menggantikan rasa tidak puas hati kelompok yang berkonflik dengan komunikasi yang harmoni. Peranan sebagai injap keselamatan yang dimainkan oleh Pejabat Menteri Besar diperkukuh dengan beberapa pendekatan supaya hubungan kumpulan luar yang berkonflik menjadi lebih efektif untuk meredakan gangguan dan tekanan terhadap sistem sosial masyarakat yang menjadi latar dalam novel Ke Hujung Usia:

"Sebagai balasan kepada senangnya berurusan dengan Tuk Aki, Exco meluluskan semua permintaan Tuk Aki seperti yang terkandung dalam kertas projek Tuk Aki itu. Ertinya Tuk Aki tidak perlu risau tentang kos pemindahan. Tuk Aki tidak perlu risau tentang pembelajaran anak-anak murid Tuk Aki. Kerajaan akan bina semula pondok, surau dan rumah sementara Tuk Aki. Apabila siap, baru Tuk Aki pindah ke sana dengan anak-anak murid Tuk Aki. Lepas itu baru rumah pusaka Tuk Aki sekarang akan dirombak dan didirikan di sana. Bagaimana?"

(A. Rahman C.M., 2018, p. 164)

Hubungan harmoni antara Tuk Aki dengan Kerajaan Negeri melalui Exco tersebut selepas konflik telah memberikan kesan positif terhadap masa depan Sekolah Pondok Haji Hamid dan seluruh pelajarnya. Malah, sekolah itu diberikan jaminan akan dipindahkan tempat yang lebih selesa, selain rumah pusaka Tuk Aki juga akan turut dipindahkan ke kawasan baharu tersebut. Berdasarkan teori konflik fungsional Coser, konflik akan meletakkan kumpulan yang berkonflik saling mendekati dan saling mengenali antara satu sama lain demi kepentingan kolektif. Secara tidak langsung, konflik Sekolah Pondok Haji Hamid dan pihak berwajib telah membantu memperkukuh struktur dan interaksi sosial antara kelompok yang berkonflik. 


\section{KESIMPULAN}

Berdasarkan pemikiran konflik fungsional Coser terhadap watak perwatakan, struktur sosial dan konflik yang dikemukakan oleh A. Rahman C.M. dalam Ke Hujung Usia, terdapat empat komponen penting yang berkaitan dengan fungsi sesebuah konflik sosial. Pertama, konflik yang bersifat kelompok dalam dan kelompok luar pada watak-watak seperti Tuk Aki, Umar dan para pelajar Pondok Haji Hamid, pegawai-pegawai Pejabat Daerah, Menteri Besar, dan Tuan Guru Haji Munir telah berjaya meningkatkan solidariti internal dan eksternal. Kedua, konflik psikologi dan konflik kelompok dalam pada watak-watak utama dalam novel ini, terutama Tuk Aki dan para pelajarnya berjaya mencegah antagonisme yang cuba dilakukan oleh kelompok lain seperti Tuan Guru Haji Munir dan para pengikutnya. Ketiga, konflik yang berlaku telah meningkatkan perkembangan ikatan sosial antara kelompok, misalnya kedudukan Tuk Aki semakin dipandang tinggi oleh pelbagai pihak hingga berjaya meletakkan beliau sebagai salah satu injap keselamatan (berdasarkan pemikiran konflik fungsional Coser) untuk mempertahankan kedudukan struktur sosial daripada menjadi mangsa konflik. Sehubungan itu, konflik antara watak merupakan rangsangan utama untuk mencapai perubahan sosial yang berhubung rapat dengan pengakuan terhadap kewibawaan Tuk Aki yang berjaya menyatukan dan mengeratkan kelompok yang berkonflik.

Kedudukan ini sejajar dengan pemikiran Coser bahawa konflik memiliki nilai fungsional dan merupakan proses instrumental dalam pembentukan, penyatuan dan pemeliharaan struktur sosial. Konflik dengan kelompok lain dapat memperkuat kembali jati diri kelompok dan melindunginya daripada berlakunya keruntuhan struktur sosial. Ertinya, konflik watak dalam $\mathrm{Ke}$ Hujung Usia berdasarkan pemikiran Coser memiliki fungsi positif untuk memperkuat struktur sesebuah kelompok (solidariti para pelajar Pondok Haji Hamid) yang mengalami konflik dengan kelompok luar (kelompok Tuan Guru Haji Munir dan Pejabat Daerah). Selain itu, konflik tersebut juga berjaya meletakkan Tuk Aki sebagai injap keselamatan untuk menghubung dan meredakan konflik kumpulan dalam dan kumpulan luar. Secara tidak langsung, pertembungan sosial antara watak dalam novel tersebut telah memperlihatkan pentingnya sumbangan konflik untuk mempertahankan kekuatan sesebuah struktur sosial. 


\section{PENGHARGAAN}

Penulis merakamkan penghargaan dan jutaan terima kasih kepada mentor dan penyelia bagi penghasilan artikel ini, iaitu Dr. Azman Ismail, Pensyarah Fakulti Penulisan Kreatif dan Filem, Akademi Seni Budaya dan Warisan kebangsaan (ASWARA).

\section{RUJUKAN}

A. Rahman C.M. (2018). Ke Hujung Usia. Kuala Lumpur: Dewan Bahasa dan Pustaka. Abrams, M.H. (1976). The Mirror and the Lamp: Romantic Theory and Critical Tradition. Oxford: University of Oxford.

Anderson, Magaret \& Collins, Patricia Hill. (1992). Race, Class and Gender. Belmont, Calif: Wadsworth.

Coser, Lewis A. (1956). Social Conflict and the Theory of Social Change. The British Journal of Sociology. 8(3), 78-96.

Coser, Lewis A. (1968). The Function of Social Conflicts (second edition). New York: McMillan Publishing.

Coser, Lewis A. (1970). Men of idea: A Sociologist's View. New York: The Free Press.

Coser, Lewis A. (1991). Introduction to Sociology. In Robert K. Merton (ed.). California: Harcourt Brace Jovanovich.

Coser, Lewis A. (2001). The Function of Social Conflicts. (Reprint Edition). New York Routledge.

Coser, Lewis A. (2012). The Idea of Social Structure. Paper in honor of Robert K. Merton (ed.). New Brunswick \& London: Transaction Publishers.

Dahrendorf, Ralf. (2018). Class and Class Conflict in Industrial Society (Classic Reprint). London: Forgotten Book.

Giddens, Antony \& Turner, Jonathan (eds.). (2004). Social Theory Today. California: Standford University Press.

Ida Bagus Wirawan. (2014). Teori-teori Sosial dalam Tiga Paradigma: Fakta Sosial, Definisi Sosial dan Perilaku Sosial. Jakarta: Prenadamedia Group.

Parekh, Bhikhu. (2015). Marx's Theory of Ideology. New York: Routledge.

Poloma, Magaret M. (1992). Contemporary Sociological Theory. London: Mcmillan. Puji Santoso. (2000). Kekuasaan, Ideologi, dan Politik dalam Dunia Kesusasteraan. Soediro Satoto \& Zainuddin Fananie (eds.), Sastera: Ideologi, Politik dan Kekuasaan. Surakarta: Muhammadiyah University Press.

Ritzer, George \& Goodman, Douglas J. (2004). Sociological Theory. New York: McGraw-Hill.

Turner, Jonathan H. (1975). The Structure of Sociological Theory. Illinois: The Dorsey Press.

Turner, Jonathan H. (2004). Handbook of Sociological Theory. California: Springer. 
MALAY LITERATURE VOLUME 33 NUMBER 2 DECEMBER 2020

Umar Junus. (1986). Sosiologi Sastera: Persoalan Teori dan Metode. Kuala Lumpur: Dewan Bahasa dan Pustaka.

Wallace, Ruth A. \& Alison Wolf. (2006). Contemporary Sociological Theory Continuing the Classical Tradition (Sixth Edition). New Jersey: Englewood Cliffs.

Weber, Robert Philips. (1990). Basic Content Analysis. London: Sage Publications.

Received: 2 May 2020

Accepted: 24 November 2020 